Contato do autor: mcsm15@terra.com.br

\title{
AS VANTAGENS DAS ATIVIDADES LABORAIS COMO FATOR DE RESSOCIALIZAÇÃO DO ENCARCERADO ENQUANTO DIREITO FUNDAMENTAL
}

\author{
THE ADVANTAGES OF INDUSTRIAL ACTIVITIES AS OF IMPRISONED \\ REHABILITATION FACTOR AS A FUNDAMENTAL RIGHT \\ Amanda da Cruz Martineti \\ Centro Universitário Internacional - UNINTER - Curitiba - Paraná - Brasil \\ Márcia Cristina Sampaio Mendes \\ Universidade de Ribeirão Preto - UNAERP - Ribeirão Preto - São Paulo - Brasil \\ Zaiden Geraige Neto \\ Universidade de Ribeirão Preto - UNAERP - Ribeirão Preto - São Paulo - Brasil
}

Resumo: O presente trabalho teve como propósito analisar as medidas adotadas no sistema carcerário para alcançar o objetivo principal da execução penal, que é a ressocialização do encarcerado, destacando-se como a de maior eficácia a atividade laboral, bem como os direitos e as contribuições benéficas decorrente deste labor para o ambiente carcerário e para o meio social. Trata-se de um estudo exploratório em que foi utilizada pesquisa bibliográfica.

Palavras-chave: Trabalho Prisional. Ressocialização. Vantagens.

Abstract: This study aimed to examine the measures adopted in the prison system to achieve the main objective of criminal enforcement, which is the rehabilitation of the imprisoned, standing out as the most effective labor activity as well as the rights and beneficial contributions due this work for the prison environment and the social environment. It is an exploratory study in which literature was used.

Keywords: Prison work. Resocialization. Advantages.

\section{Considerações Iniciais}

A Lei de Execução Penal em seu artigo $1^{\circ}$ contemplou a ressocialização do encarcerado como o objetivo fundamental do cumprimento da pena. Entrementes, muito se discute sobre a impossibilidade da ressocialização de 
pessoas segregadas em penitenciária sob a justificativa da falência do sistema carcerário e da falta de condições mínimas de habitação no interior das celas. Por esse motivo, o presente estudo utilizará a metodologia de levantamento bibliográfico, com o propósito de analisar a contribuição da atividade laborativa como um instrumento efetivo para obtenção do êxito na ressocialização do apenado. Para tanto, serão abordadas as peculiaridades do trabalho prisional, seu enquadramento como relação empregatício, os direitos trabalhistas garantidos, a Justiça competente para julgar os conflitos decorrentes da relação de trabalho prisional e os seus reflexos benéficos.

\section{Direitos fundamentais assegurados ao encarcerado}

Os direitos fundamentais dos encarcerados começaram ser reconhecidos mundialmente no período entre as duas grandes guerras da Europa, por meio de documentos internacionais, os quais são: elaboração de regras para tratamento dos presos pela Comissão Internacional Penitenciária (1929), aprovação dessas regras pela Liga das Nações Unidas (1934), aprovação de nova versão dessas regras pela Organização das Nações Unidas, como regras mínimas de tratamento de presos (1955), recomendação do IV Congresso das Nações Unidas, de aplicação dessas regras (1970), Resolução $n^{\circ}$ 2.858, da Organização das Nações Unidas, determinando a implantações de regras mínimas pelos Estados Membros (1971), nova recomendação da Organização das Nações Unidas, pela Resolução n 3.218 (1974) e V Congresso da Organização das Nações Unidas, publicando-se, pelo Secretariado, trabalho de grande expressão sobre as regras mínimas de atendimento ao preso (1975) (BENETI, 1996).

Não obstante os documentos internacionais tratem dos direitos dos presos, as legislações nacionais os disciplinam no artigo $5^{\circ}$, inciso XLIX, da Constituição Federal, no artigo 38, do Código Penal, e no artigo $3^{\circ}$, da Lei de Execução Penal, que estabelecem a preservação dos direitos, salvo aqueles atingidos pela condenação e os decorrentes de expressa previsão legal.

Destarte, os condenados a pena privativa de liberdade, embora sejam privados de seu direito de livre locomoção, não perdem a sua condição de pessoa humana e a titularidade dos direitos não atingidos pela condenação. 
Assim, é correto afirmar que os direitos dos presos consistem, também, em direitos humanos, os quais são conceituados como "direitos que naturalmente correspondem a cada pessoa pelo simples fato de serem seres humanos e em razão da dignidade a tal condição e às de liberdade, segurança, igualdade, justiça e paz em que toda pessoa deve viver e atuar" (MIRABETE, 2007, p.118). Portanto, são direitos invioláveis, imprescritíveis e irrenunciáveis.

A preservação dos direitos durante o período de encarceramento é um fator benéfico para a reintegração social, porque, se fosse ao contrário, ou seja, ao ser preso, perdesse a sua titularidade de direitos e deveres, quando retornasse ao seio social se sentiria alienígena, carente de readaptação e, em razão disso, a pena não estaria cumprindo uma de suas funções, qual seja o de segregar com o objetivo de reeducar e ressocializar o infrator.

Malgrado nas legislações, inclusive na Carta Magna, teoricamente

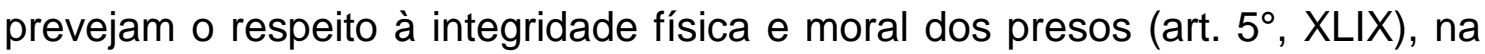
realidade eles são desprovidos de condições mínimas e fundamentais para sua sobrevivência, visto que os presídios estão superlotados, não possuindo higiene, água, esgoto, tratamento médico e hospitalar, o que contribui para falência do sistema carcerário e para frustração das funções da pena.

Por isso, são assegurados aos encarcerados a utilização de instrumentos judiciais contra excessos ou desvios, como habeas corpus e mandado de segurança, com a finalidade de proteger os seus direitos e impedir que não sejam observados.

Conforme amplamente descrito, o infrator tem seus os direitos fundamentais aos preservados, desde que compatíveis com sua condição de encarcerado e, em virtude disso, a CLT (Consolidação das Leis do Trabalho) estabelece no art. 482, alínea d, a dispensa por justa causa do empregado cuja condenação criminal tenha transitado em julgado.

É importante trazer à baila o referido dispositivo:

Art. 482 - Constituem justa causa para rescisão do contrato de trabalho pelo empregador:

d) condenação criminal do empregado, passada em julgado, caso não tenha havido suspensão da execução da pena 
Por consequência deste dispositivo o empregado perde o emprego e, com isso, a possibilidade de se manter minimamente integrado à sociedade que um dia pretende se reintegrar.

Por este motivo, surge o direito ao trabalho garantido ao preso, porque se condenado à pena privativa de liberdade fica limitado em seu direito de locomoção, não podendo continuar exercendo sua atividade laboral anterior e, por isso, incumbe ao Estado o dever de garantir-lhe o direito ao trabalho, que pode ser realizado internamente no estabelecimento prisional ou externamente.

Esse direito tem a finalidade de retirar o encarcerado da ociosidade e reingressá-lo em uma atividade produtiva, evitando, assim, a formação de grupos de organização criminosa dentro do presídio e proporcionar melhor qualidade de vida.

\subsection{Trabalho prisional no Direito Brasileiro}

O trabalho prisional está previsto em inúmeras normas jurídicas, sendo a primeira o Código Criminal de 1830, o qual disciplinava a obrigação do condenado de laborar diariamente, no interior dos presídios, sendo considerado trabalho forçado, uma vez que possuía caráter punitivo (TRISOTTO, 2005).

Atualmente, a atividade laboral possui caráter educativo, pois 0 encarcerado adquire uma capacitação profissional, com o propósito de ser preparado para o retorno à sociedade e o ingresso no mercado de trabalho. Ainda, evita o ócio e, por consequência, a reincidência.

As principais normas jurídicas atinentes ao trabalho prisional estão previstas no Código Penal em seus artigos 34, 35, 39 e 83, inciso III, na Lei $n^{\circ}$ 7.210/1984 (LEP), em seus artigos 28, 29, 31, 32, 33, 34, 35, 36, 37, 39, inciso V, 41, incisos II, III, V e VI e parágrafo único, 44, 50, incisos IV e VI, 55, 83, caput, 114, inciso I e parágrafo único, 126, 127, 128, 129, 130, 138 e 200, embora existam outras que mencionam o trabalho exercido nas prisões (OLIVEIRA, 2008).

No entanto, não existe nenhum dispositivo na Consolidação das Leis do Trabalho (CLT) que regulamente o trabalho do encarcerado e, inclusive, o 
artigo 28, parágrafo $2^{\circ}$, da Lei de Execução Penal, disciplina que "o trabalho do preso não está sujeito ao regime da Consolidação das Leis do Trabalho".

Inobstante o trabalho penitenciário esteja amplamente disciplinado pelo legislador pátrio, as normas não são efetivamente aplicadas, pois o Estado brasileiro tem sido historicamente incompetente para prover trabalho ao preso, inviabilizando-se, assim, a ressocialização por meio desse instrumento tão eficaz.

\subsection{Natureza jurídica do trabalho prisional}

Não existe um posicionamento pacificado sobre a natureza jurídica do trabalho prisional. Porém, o majoritário é no sentido de que está desvinculada da relação de emprego, já que, conforme visto preteridamente, a condenação transitada em julgado, rompe automaticamente o vínculo empregatício. Desse modo, o fundamento primordial da corrente majoritária está na falta de liberdade do encarcerado para manifestar sua vontade na execução o labor, pois o trabalho tem feição de dever, sendo obrigatória a sua realização, sob pena de incorrer em falta disciplinar grave. Outro argumento desta corrente consiste no fato de o trabalho do preso não estar sujeito ao regime da Consolidação das Leis do Trabalho, conforme o artigo 28 , parágrafo $2^{\circ}$, da Lei de Execução Penal e, por isso, não tem natureza de relação empregatícia.

Todavia, há críticos que entendem de maneira distinta, sustentando a possibilidade de o trabalho prisional ter natureza jurídica de relação de emprego e refutando o posicionamento da corrente majoritária de que o serviço laboral é um dever do encarcerado, visto que defende ser um direito, não podendo o Estado utilizar-se de qualquer meio para obrigá-lo, até porque a Constituição Federal em seu artigo 5º, incisos XIII e XLVII, alínea "C", disciplinou que "é livre o exercício de qualquer trabalho, ofício ou profissão, atendidas as qualificações profissionais que a lei estabelecer" e "não haverá penas de trabalhos forçados".

Para esta corrente, ainda que o trabalho do preso fosse considerado como dever, a natureza dele poderia se enquadrar na relação de emprego, porque de acordo com a teoria anticontratualismo, a vontade do contratado é irrelevante, prescindível, para a validade do vínculo empregatício, pois o que 
importa é a realidade concreta e o preenchimento dos demais requisitos (onerosidade, subordinação, habitualidade e pessoalidade) (PENAFORT, 2009).

Destarte, não é o consentimento que determina a natureza jurídica da relação do trabalho carcerário, mas sim a finalidade do trabalho efetuado, que é a satisfação do binômio educação-produção (artigo 28, da Lei de Execução Penal). Por isso, se a atividade laboral realizada pelos encarcerados desviar da finalidade, isto é se prevalecer o aspecto produtivo em detrimento do aspecto educativo, a finalidade está desviada, reconhecendo-se, assim, a relação de emprego, como se dá na relação laboral de estágio quando descumprida a finalidade, gerando como consequência a caracterização da relação de emprego assegurando-se todos os respectivos direitos.

Nesta linha é o acórdão proferido pelo Tribunal Superior do Trabalho ao decidir reclamação sobre este assunto, em que reconheceu a possibilidade do trabalho celetista para o encarcerado: "Não impede a lei que possa o presidiário custodiado estabelecer uma relação de trabalho subordinado, não Ihe faltando capacidade para contratar, aplicando-lhe a legislação trabalhista em toda plenitude" ( $2^{\circ}$ Turma - Recurso de Revista 314/73, de 15 de maio de 1973 - rel. Min. Costa Monteiro).

Portanto, dependendo da finalidade efetiva, pode vir o trabalho prisional ter a natureza jurídica de relação de emprego, mesmo que o artigo 28 , parágrafo $2^{\circ}$, da Lei de Execução Penal, tenha determinado a exclusão do trabalho do preso da Consolidação de Leis do Trabalho, pois existem leis extravagantes normatizando relações empregatícias, como é o caso dos trabalhadores domésticos.

Por fim, existe também um posicionamento mais radical no sentido de enquadrar o trabalho prisional, ainda que não desvie de sua finalidade, como relação empregatícia, bastando os preenchimentos onerosidade, subordinação, habitualidade e pessoalidade, equiparando-o a um trabalho livre.

\subsection{Relação de emprego do encarcerado}

No posicionamento da corrente minoritária, o trabalho carcerário gera 0 vínculo empregatício desde satisfaça os cinco elementos: a) prestação de 
trabalho efetuada por pessoa física com b) pessoalidade, c) não eventualidade, d) sob subordinação jurídica e e) onerosidade, todos previstos no artigo $3^{\circ}$ da CLT, conforme abaixo:

Art. $3^{\circ}$ - Considera-se empregado toda pessoa física que prestar
serviços de natureza não eventual a empregador, sob a dependência
deste e mediante salário.
Parágrafo único - Não haverá distinções relativas à espécie de
emprego e à condição de trabalhador, nem entre o trabalho
intelectual, técnico e manual.

a) Pessoa Física é a pessoa natural dotada de energia produtiva capaz de efetuar um labor. Destarte, não consistirá em relação de emprego quando o contratado for pessoa jurídica ou ente despersonalizado.

b) Pessoalidade significa que o encarcerado trabalhador não poderá fazer-se substituir por outrem na prestação de serviço pactuada, caracterizando-se, assim, relação jurídica intuitu personae.

c) Não eventualidade consiste na habitualidade da prestação de serviços pelo preso, de maneira não esporádica, o que não significa laborar todos os dias. A jurisprudência de forma dominante entende como habitualidade três ou mais vezes por semana para permitir a configuração do vínculo empregatício.

d) Subordinação jurídica é o acatamento das ordens do empregador pelo empregado, desde que lícitas e contratuais. Trata-se de prestação de serviços sob comando do tomador de serviços e caracteriza sem sombra de dúvidas no elemento mais diferenciador da relação de emprego em contraposição às outras formas de prestação de serviços.

e) Onerosidade é a contraprestação recebida pelo trabalhador em decorrência dos serviços efetuados. Dessa forma, para que haja a relação de emprego o labor nunca poderá ser gratuito.

Registra-se que preenchidos cumulativamente os requisitos supracitados o encarcerado assume a posição de empregado e a qualidade de titular dos direitos trabalhistas. Contudo, na ausência de um dos elementos descaracteriza o vínculo empregatício.

\section{Direitos trabalhistas do encarcerado}


Preenchimento os requisitos sobreditos, os presos terão garantidos apenas alguns direitos trabalhistas, em razão das peculiaridades de seu labor e com a finalidade de permanecer atrativa a contratação de mão de obra encarcerada por parte das empresas privadas.

Conforme já suscitado, por expressa previsão do artigo 28, parágrafo $2^{\circ}$, da Lei de Execução Penal, não se aplica à Consolidação das Leis trabalhistas ao trabalho prisional, entretanto, devem ser observados os direitos trabalhistas reconhecidos na Constituição Federal, em seu artigo $7^{\circ}$, nas Normas Regulamentadoras expedidas pelo Ministério do Trabalho e Emprego e nas Convenções da Organização Internacional do Trabalho. Defender posição contrária equivaleria à defesa do trabalho análogo ao escravo.

Destarte, os empregados presos têm como direitos assegurados em razão da prestação do serviço: a assinatura da carteira de trabalho e previdência social (CTPS), o salário, a limitação na jornada de trabalho, a participação nos lucros e resultados, o adicional de periculosidade e insalubridade, o fundo de garantia do tempo de serviço e as férias.

O primeiro direito assegurado ao preso em virtude da relação de emprego é a assinatura da carteira de trabalho, no prazo de quarenta e oito horas da sua admissão, com a finalidade de anotar a data do início do labor, a contraprestação e as condições especiais (DELGADO, 2007).

Em contraprestação ao trabalho exercido, o encarcerado receberá remuneração não inferior a três quartos do salário mínimo, com fulcro no artigo 29, da Lei de Execução Penal. A partir desta previsão, discute-se se este artigo viola a Constituição, porque esta estabelece no artigo $7^{\circ}$, incisos IV e VII, que o salário nunca será inferior ao mínimo. Contudo, na visão do jurista Paulo Fernando dos Santos "a norma sob comento traz regra especial, cuja imposição é plenamente válida, eis que, no caso, existe um contrato, de trabalho específico, de caráter público, com natureza absolutamente diversa do contrato firmado pelos trabalhadores em geral" (SANTOS, 1999, p.76).

A jornada de trabalho do encarcerado foi instituída de maneira similar a do trabalho livre, com o propósito de que, quando retornar à liberdade, já esteja habitualizado com uma rotina diária de trabalho, possibilitando, com maior facilidade, adaptação a seu novo serviço. 
Dessa maneira, a Lei de Execução Penal, em seu artigo 33, estabeleceu o lapso temporal máximo de oito horas e mínimo de seis horas para a jornada de trabalho, com direito aos descansos nos domingos e feriados, para que 0 preso recomponha sua energia despendida durante toda a semana e se evite acidente de trabalho em virtude do cansaço. O descanso poderá recair em outro dia da semana que não no domingo, quando o trabalho executado consistir em conservação e manutenção do estabelecimento prisional. Todavia sua jornada diária não poderá exceder oito horas nem ser inferior a seis horas (MIRABETE, 2007).

O trabalhador encarcerado também é titular do direito de participação nos lucros e resultados da empresa, uma vez que a nossa Carta Magna não o excluiu (BAQUEIRA, 2008). Assim, é coerente que a empresa partilhe seus lucros com os presos trabalhadores, em função de se beneficiar com a mão de obra barata e auferir uma margem maior de lucro. Todavia, como não há nenhuma lei que obrigue o empregador a repartir seus lucros, quase que a maioria dos empregados não os recebem.

Conquanto os adicionais de periculosidade e insalubridades estejam previstos na Consolidação das Leis de Trabalho, em seus artigos 189 e 190, tais direitos precedem o retrocitado diploma normativo, estando contemplados nas Convenções 155 e 170 da Organização Internacional do Trabalho, portanto também são assegurados aos detentos (BAQUEIRO, 2008).

As férias também é um direito assegurado aos encarcerados, porque sua previsão está contemplada na Convenção 132 da Organização Internacional do Trabalho e no artigo $7^{\circ}$, inciso XVII, da Carta Magna. Entretanto, durante as férias não poderão ficar com sua família todos os dias e nem tampouco se retirar do estabelecimento prisional (BAQUEIRO, 2008).

\subsection{Direitos trabalhistas não garantidos aos presos}

O exercício do labor prisional não enseja conforme enunciado supra, a garantia de todos direitos trabalhistas, porque senão o tornaria paritário ao trabalho livre, que é excessivamente oneroso ao empregador e, assim, as empresas não teriam vantagens em contratar a mão de obra carcerária, a qual 
certamente seria abolida, inviabilizando-se, por consequência, a ressocialização, por meio do instrumento mais eficaz, o trabalho.

Os direitos não garantidos ao empregado preso são a filiação ao sindicato, a aplicação de convenção e acordos coletivos, a greve e o aviso prévio, dentre outros.

A liberdade de o trabalhador se filiar ao sindicato está previsto o artigo $8^{\circ}$, da Lei Maior, entrementes, entende-se que tal dispositivo não ampara 0 trabalhador recluso, pelo risco trazido à segurança do estabelecimento prisional e a própria sociedade, porque o sindicato tem a função de defender e coordenar os interesses econômicos ou profissionais dos empregados (BAQUEIRO, 2008). Dessa forma, os presos não satisfeitos com as atividades laborais exercidas e influenciados pelos pensamentos protetivos sindicais poderiam se rebelar e reivindicar alguns direitos incompatíveis com a condição de encarcerado.

Malgrado a Recomendação $\mathrm{n}^{\circ} 163$, da Organização Internacional do Trabalho, e as Convenções números 98 e 154, da Organização Internacional do Trabalho, tenham regulado a possibilidade da aplicação dos acordos e convenções coletivas a qualquer tipo de empregado, que desempenha qualquer função, em todos os lugares em que possa exercer o labor, não seria coerente a aplicação das negociações coletivas aos reclusos, porque diante da amplitude dos direitos assegurados por estes instrumentos a contratação da mão de obra carcerária seria desestimulada e não incentivada.

Nesse diapasão é o posicionamento de Fernanda Ravazzano Lopes Baqueiro:

Se fossem aplicados os preceitos contidos nas convenções coletivas de trabalho e nos acordos coletivos, como por exemplo, o piso salarial, ampliação da jornada de trabalho ou redução da mesma, dentre outras possibilidades, não haveria na prática qualquer vantagem financeira para a contratação do preso (BAQUEIRO, 2008, p.5.144).

O direito de greve não se estende ao trabalhador preso, porque o seu exercício configura falta disciplinar grave, conforme previsto no artigo 50, da Lei de Execução Penal: "comete falta disciplinar o condenado à pena privativa de liberdade que incitar ou participar de movimento para subverter a ordem ou a disciplina". Outrossim não é garantido aos encarcerados o direito de greve por 
questões de segurança pública, tendo em vista que o seu exercício envolve inúmeras pessoas, podendo, acarretar rebeliões e desordem no estabelecimento prisional.

O aviso prévio não é aplicado na rescisão unilateral do contrato firmado entre o preso e o empregador. Destarte, se aquele não desejar mais laborar, não será razoável a aplicação de qualquer sanção, pois a remuneração que recebe é pequena e não comporta qualquer desconto a título de indenização. Nesta hipótese em que o preso não queira mais exercer a atividade laboral, incumbe ao Estado à escolha de outro para trabalhar.

Da mesma forma, não se pode exigir que o empregador pague qualquer quantia referente ao aviso prévio, porque acarreta a ele um ônus considerável, o que diminui o interesse em contratar detentos.

\section{Justiça competente para solucionar os conflitos decorrentes da relação de trabalho prisional}

A competência material da Justiça do Trabalho, a partir da Emenda Constitucional $n^{\circ} 45$ de 2004, passou a abranger o julgamento de todas as das ações decorrentes da relação de trabalho e outras matérias relacionadas com o labor, não a limitando como antes, a analisar e julgar somente os conflitos referentes à relação de emprego.

Todavia, conforme posicionamento de Amauri Mascaro do Nascimento, na relação de trabalho, que abrange diversas situações jurídicas, os magistrados aplicarão o direito material referente a esses vínculos, ao passo que, na solução dos litígios sobre a relação de emprego, aplicarão a Consolidação das Leis Trabalhistas (NASCIMENTO, 2007). Esta distinção na aplicação da lei material, contudo, não gera interferência na definição do quinhão competencial como resulta cristalino.

De acordo com a ampliação da competência material da Justiça do Trabalho, ainda que o trabalho prisional não se enquadre como relação empregatícia, seria uma relação de trabalho e, por consequência, julgada na Justiça do Trabalho. Nesse sentido, a Justiça do Trabalho, por ter maior conhecimento técnico na área relativa ao trabalho prisional, evitaria a ocorrência de erros e garantiria um julgamento imparcial baseado na figura do 
trabalhador, desvinculado da ideia de punição, o que não é comum no juízo das execuções penais, que enfatiza a figura do preso.

No entanto, este posicionamento não é unânime, encontrando diversas resistências, com o fundamento de que seria a Justiça Comum, por meio dos magistrados que atuam nas execuções penais, a competente para julgar os litígios derivados da relação de trabalho prisional, porque este é realizado durante a fase de cumprimento da pena (execução penal). Neste sentido, qualquer litígio sobre os direitos conferidos pelo trabalho penitenciário deve ser apreciado pelo juízo das execuções penais, de modo que a Justiça do Trabalho seria incompetente ex ratione materiae para o julgamento das demandas que tratem de conflitos derivados da relação essencialmente vinculada ao Direito Penal, tendo em vista que essa relação não está abrangida no artigo 114, da Carta Magna, que disciplina a competência material dessa Justiça.

Além do mais, outro argumento que corrobora este posicionamento refere-se ao artigo 28, parágrafo $2^{\circ}$, da Lei de Execução Penal, que prevê que a atividade laboral realizada nas prisões não se sujeita à Consolidação das Leis do Trabalho.

Nesse sentido é o seguinte julgado:

RECURSO ORDINÁRIO - TRABALHO PRISIONAL - REGIME
FECHADO - JUSTIÇA DO TRABALHO - INCOMPETÉNCIA
MATERIAL.
1. Considerando que o trabalho realizado por preso em regime
fechado se insere nas obrigações decorrentes do cumprimento da
sua pena, resta ausente um dos caracteres integrantes da natureza
jurídica do contrato de trabalho, qual seja, o livre consentimento das
partes, de forma a afastar a competência desta Especializada para
solucionar os conflitos atinentes a essa relação. Demais disso, o
trabalho prestado nessas condições é disciplinado pela Lei de
Execução Penal (no $7.210 / 84$ ), possuindo especificidades que melhor
serão dirimidas pelo juízo da execução da pena. Registre-se,
também, que a LEP, em seu artigo $28, \S 2^{\circ}$, exclui, expressamente, a
aplicação das disposições previstas na CLT ao trabalho prisional.
2. Recurso improvido.
(TRT6-RO RO 1316200701606006 PE 2007.016 .06 .00 .6$)$

Malgrado não exista consenso sobre esse tema, entendemos que seria mais adequado a Justiça do Trabalho apreciar e dirimir os litígios surgidos da relação de trabalho prisional, porque não existe nenhuma lei que exclua a relação de trabalho prisional da relação de trabalho gênero, prevista no artigo 114, inciso I, da Constituição Federal, não se restringindo assim esse conceito, 
o que permite a competência da Justiça do Trabalho para julgar as lides oriundas da relação prisional, bem como a Justiça do Trabalho é mais apta para decidir questões que decorram do trabalho, pois tem conhecimento específico sobre a causa, diminuindo os riscos de falhas e possibilitando maior celeridade.

Nesta hipótese, a competência da Justiça do Trabalho somente abrangeria os litígios relativos aos direitos originados do exercício da atividade prisional, excluindo os efeitos do trabalho prisional sobre a pena, cuja competência seria do juízo das execuções penais.

\section{Os efeitos do trabalho prisional}

O trabalho prisional enseja inúmeros efeitos, seja no cumprimento das penas, como o instituto da remição, como na vida do preso, permitindo a sua ressocialização.

$\mathrm{Na}$ lição do Julio Fabrinni Mirabete, a remição é "um direito do condenado em reduzir pelo trabalho prisional o tempo de duração da pena privativa de liberdade cumprida em regime fechado e semiaberto. Trata-se de um meio de abreviar ou extinguir parte da pena" (MIRABETE, 2007, p. 517).

Dessa forma, o condenado em regime fechado ou semiaberto tem direito de, a cada três dias trabalhados, descontar um dia de pena.

Já a ressocialização do encarcerado, que é finalidade expressa da Lei de Execução Penal, em seu artigo $1^{\circ}$, nem sempre é efetivada diante dos problemas do sistema carcerário. A principal dificuldade na concretização dessa finalidade é o desrespeito aos direitos dos apenados e o não reconhecimento de sua dignidade humana, uma vez que o ambiente em que vivem é superlotado, se assemelhando a um depósito de pessoas, incompatível com a reabilitação. Diante desse cenário, verifica-se que o índice de reincidência é altíssimo, situado entre $60 \%$ e $70 \%$. Portanto, atualmente o desafio de nosso sistema prisional é encontrar instrumentos eficientes para conduzir os encarcerados à condição de cidadão, de modo que, ao final da execução de sua reprimenda, estejam preparados para conviver no meio social. 
De forma majoritária, os doutrinadores citam o trabalho e a educação como tais meios que ensejam a reintegração social, sendo imperioso, para alcançá-la, o investimento do Estado na construção de oficinas e salas de aulas.

A atividade laborativa gera na vida do encarcerado diversas vantagens, que se refletem internamente e externamente à penitenciária (intra e extramuros). Enquadram-se como benefícios internos a remição; a qualificação e o aperfeiçoamento profissional; a melhora na disciplina; a ocupação mental e física, que impede o ócio presente no ambiente prisional, evita a pensamento voltado à criminalidade e promove a recuperação da autoestima do preso e a sua valorização como ser humano, entre outros. Por sua vez, as vantagens externas atingem tanto o egresso como a sociedade, pois aquele teve a oportunidade de adquirir novos valores e aprender um ofício, retornando à vida em liberdade com a possibilidade elevada de respeitar às regras penais, ingressar no mercado de trabalho mais preparado e evitar a reincidência. Portanto, se o egresso tiver esse comportamento, a sociedade é a principal favorecida, uma vez que terá maior segurança e menos violência.

Embora o trabalho seja a melhor ferramenta de reintegração social, o Estado não o coloca a disposição de todos os encarcerados, mesmo constituindo-se seu dever, conforme se verifica pelos dados divulgados na Revista da Indústria, de abril de 2010, reveladores de que no Estado de São Paulo são cento e cinquenta e sete mil presos, entre homens e mulheres, estando somente quarenta mil laborando no regime fechado ou semiaberto.

Por fim, registra-se que é preciso com urgência a expansão do trabalho e da educação em todas as unidades prisionais e para todos os detidos, pois, em contrário, as consequências serão ainda mais devastadoras, acentuandose a reincidência e frustrando-se a finalidade da execução penal. Destarte, somente com a adoção dessas medidas os estabelecimentos prisionais efetivamente cumprirão o seu papel e deixarão de ser chamados vulgarmente como fábrica e escola do crime, tendo em vista que o encarcerado, ao invés de se ressocializar, retorna ao meio social mais perigoso. 


\section{Conclusão}

Com a concretização do presente trabalho conclui-se que a relação de trabalho prisional pode gerar vínculo empregatício, desde que presentes a pessoalidade, a habitualidade, a subordinação jurídica e a onerosidade, requisitos da relação de emprego. A ausência de um desses elementos inviabiliza o reconhecimento do vínculo empregatício, existindo somente a relação de trabalho.

Todavia, há doutrinadores que sustentam a impossibilidade do reconhecimento do vínculo empregatício nas atividades laborais executadas pelos encarcerados, com fundamento na falta de liberdade do preso para manifestar a sua vontade na formação do contrato de trabalho, porque o trabalho prisional segundo a Lei de Execução Penal constitui um dever. Entretanto, esse argumento é, de maneira consistente, afastado pela teoria denominada anticontratualista que considera relevante para formação do contrato de trabalho os requisitos da pessoalidade, da habitualidade, da subordinação jurídica e da onerosidade, sendo prescindível a vontade do contratado. Dessa forma, é possível o reconhecimento da relação empregatícia no labor executado pelo encarcerado, ainda que esse seja obrigado a trabalhar na forma da lei.

Outrossim a grande maioria dos juristas defende que 0 trabalho prisional não gera vínculo empregatício, porque 0 artigo 28 , parágrafo $2^{\circ}$, da Lei de Execução Penal, disciplinou que tal labor não se sujeita à Consolidação das Leis do Trabalho. Contudo, esse pensamento não deve prevalecer, tendo em vista que existem leis extravagantes normatizando relações empregatícias, como o caso dos empregados domésticos. Nesse diapasão, o simples fato de não se aplicar a Consolidação das Leis do Trabalho não impede a configuração da relação de emprego.

Dessa forma, quando estiver configurada relação empregatícia entre os encarcerados e o tomador de serviços, devem ser garantidos àqueles alguns direitos trabalhistas. Caso contrário, os apenados estariam desprotegidos e as empresas tomadoras de serviços explorariam a mão de obra carcerária com a finalidade de redução das suas despesas e obtenção de maiores lucros, desvirtuando a função do trabalho prisional, traduzida no binômio, educação e 
produtividade, e até mesmo causando concorrência desleal com os trabalhadores livres, que deixariam de ser contratados, pois a sua contratação geraria maiores custos para o empregador.

Os direitos trabalhistas garantidos aos presos trabalhadores estão previstos no artigo $7^{\circ}$, da Constituição Federal, e nas Convenções da Organização Internacional do Trabalho, os quais são garantias para qualquer espécie de trabalhador, contudo não poderão ser aplicados a eles os direitos trabalhistas disciplinados na Consolidação das Leis do Trabalho, por expressa previsão do artigo 28, parágrafo $2^{\circ}$, da Lei de Execução Penal.

Ademais, não são todos os direitos trabalhistas normatizados na Constituição Federal e nas Convenções da Organização Internacional que devem ser observados na relação empregatícia do encarcerado, porque poderia tornar onerosa a sua contração, o que desestimularia as empresas a contratar a mão de obra carcerária, prejudicando o trabalho prisional e, por consequência, a sua função ressocializante.

A execução da pena tem a função essencial de ressocializar os presos, a qual somente será alcançada de maneira eficaz por meio do trabalho prisional, tendo em vista que esse possibilita inúmeras vantagens que conduzem à reinserção social. As vantagens significativas consistem na qualificação profissional, assunção de comportamento mais regrado, aprendizagem de um ofício e outras, que contribuem de forma mais célere para que o egresso conquiste um emprego na sua nova vida em liberdade. A aquisição de emprego fora da prisão é um dos fatores mais importantes para evitar a reincidência e o retorno ao estabelecimento prisional, porque o egresso receberá um salário para suprir suas necessidades básicas, sem recorrer à prática de delito para isso.

É certo que o trabalho prisional é um fator ressocializante presente nas prisões, porque apenas gera consequências positivas, todavia é imprescindível que ele esteja aliado ao respeito aos direitos dos apenados, às condições mínimas de higiene e de estrutura nos estabelecimentos prisionais e a alimentação adequada. No entanto, o sistema carcerário brasileiro atual é dramático, pois se observam nele superlotação, maus tratos, falta de higiene, insuficiência de vagas para o trabalho e, quando existem, as condições são deficientes, má alimentação e outros, que se contrapõem ao objetivo essencial 
da execução penal. Além do mais, ensejam ódio e sentimento de vingança ao encarcerado e, dessa forma, a execução penal, em lugar de ressocializar, está profissionalizando criminosos.

Diante do exposto, é necessário que o Estado, com a máxima urgência, dê mais atenção ao ambiente carcerário, transformando-o em um local que tenha condições mínimas para ser habitado e coloque à disposição de todos os encarcerados as atividades laborativas, porque só assim o propósito da execução penal será concretizado, isto é, alcançar a ressocialização. Caso contrário, as consequências serão ainda mais devastadoras de forma a fomentar ainda mais a reincidência.

\section{Referências}

ALMEIDA, André Luiz Paes de. Direito do Trabalho. $8^{\circ}$ edição. São Paulo: Rideel, 2010.

ALVIM, Rui Carlos Machado. Trabalho Penitenciário e os Direitos Sociais. São Paulo: Atlas, 1991.

BAQUEIRO, Fernanda Ravazzano Lopes. Da Necessidade da Declaração e Respeito aos Direitos Trabalhistas dos Presos e o Papel do Ministério Público do Trabalho no combate à Exploração de Mão de Obra Carcerária. 2008. Disponível em $<$ http://www.conpedi.org.br/manaus/arquivos/anais/salvador/fernanda ravazzan o lopes baqueiro.pdf $>$. Acesso em 03 de agosto de 2010.

BITENCOURT, Cezar Roberto. Tratado de Direito Penal- Parte Geral. vol. 1. $11^{\circ}$ edição. São Paulo: Saraiva, 2007.

BRANT, Vinicius Caldeira. O Trabalho encarcerado. Rio de Janeiro: Forense, 1994.

CAPEZ, Fernado. Curso de Direito Penal- Parte Geral. vol. 1. 11ํe edição. São Paulo: Saraiva, 2007.

CASELLA, João Carlos. O presidiário e a previdência social no Brasil. Revista de Legislação do Trabalho e Previdência Social, abril 1980.

COSTA, Alexandre Marino. Trabalho Prisional e a Reintegração Social do Detento. Florianópolis: Insular, 1999.

DE JESUS, Damásio. Direito Penal- Parte Geral. 1ํvol. 28ํe edição. São Paulo: Saraiva, 2005. 
DELGADO, Mauricio Godinho.Curso de Direito do Trabalho. $6^{\circ}$ edição. São Paulo: LTr, 2007.

DEMERCIAN, Pedro Henrique, MALULY, Jorge Assaf. Curso de Processo Penal. 5o edição. Rio de Janeiro: Forense, 2009.

FERREIRA, Michel Sparvoli Jobim. O Trabalho Prisional à Luz da Nova Competência da Justiça do Trabalho. 2006. Disponível em:

$<$ https://www.ucpel.tche.br/ojs/index.php/ PENIT/article/viewFile/280/260>. Acesso em: 28 de agosto de 2010.

GERAIGE NETO, Zaiden. O princípio da inafastabilidade do controle jurisdicional. São Paulo: RT, 2003.

LEMOS, Ana Margarete, MAZZILLI, Cláudio, KLERING, Luís Roque. Análise do Trabalho Prisional: um Estudo Exploratório. 1998. Disponível em: <http:/ www.scielo.br/ pdf/rac/v2n3/v2n3a08.pdf.>. Acesso em: $1^{\circ}$ de setembro de 2009.

LYRA, Raphaela Barbosa Neves. Trabalho prisional Mão-de-obra explorada $x$ Política pública protetiva. 2007. Disponível em:

$<$ http://www.frb.br/ciente/dossie/dossie lyra.pdf $>$. Acesso em: 31 de outubro de 2010.

MACHADO, Antônio Alberto. Curso de Processo Penal. $3^{\circ}$ edição. São Paulo: Atlas, 2010.

MALTA, Christovão Piragibe Tostes. Prática do Processo Trabalhista. $35^{\circ}$ edição. São Paulo: LTr, 2008.

MARCÃO, Renato Flávio, Lei de Execução Penal Anotada. São Paulo: Saraiva, 2001.

MARCÃO, Renato Flávio, Curso de Execução Penal.7 edição. São Paulo: Saraiva, 2009.

MARTINS, Sergio Pinto. Direito do Trabalho. $24^{\circ}$ edição. São Paulo: Atlas, 2008.

MATURANA, José Fernando Ruiz. Considerações sobre o trabalho do preso. Curitiba: Gênesis. Revista de Direito do Trabalho n¹05, 2001.

MIRABETE, Julio Fabrinni.Execução Penal.11º edição. São Paulo: Altas, 2007.

MIRABETE, Julio Fabrinni.Manual de Direito Penal- Parte Geral. vol.1. 23o edição. São Paulo: Atlas, 2006.

MORAES, Alexandre de. Direito Constitucional. $23^{\circ}$ edição. São Paulo: Atlas, 2008. 
NASCIMENTO, Amauri Mascaro do. Curso de Direito do Trabalho. $23^{\circ}$ edição. São Paulo: Saraiva, 2008.

NASCIMENTO, Amauri Mascaro do. Curso de Direito Processual Trabalhista. $22^{\circ}$ edição. São Paulo: Saraiva 2007.

NUCCl, Guilherme de Souza. Manual de Processo Penal e Execução Penal. $3^{\circ}$ edição. São Paulo: RT, 2007.

PENAFORT, Wueber Duarte. Natureza Jurídica da Relação de Trabalho no Cárcere. 2009. Disponível em <http://www.buscalegis.ufsc.br/revistas/index.php/article/viewFile/33047/32227> .Acesso em: 04 de agosto de 2010.

OLIVEIRA, Maxwel Caixeta de; PAULA, Gáudio Ribeiro. O Trabalho do Preso e seus Direitos: uma Perspectiva da Situação no Distrito Federal. 2008.

Disponível em

$<$ http://www.uj.com.br/publicacoes/doutrinas/4454/O Trabalho do Preso e se us Direitos uma Perspectiva da Situacao no Distrito Federal $>$. Acesso: em 03 de agosto de 2010.

SADD, Iara Lima Bentes. Segunda Chance. Revista da Indústria, ano 10, $\mathrm{n}^{\circ}$ 159, abril 2010.

SADDY, André. Trabalho do preso à luz da previdência social. 2001. Disponível em: <http://www.fiscosoft.com.br/a/2bzu/trabalho-do-preso-a-luz-daprevidencia-social-andre-saddy-elaborado-em-082001>. Acesso em: 08 de agosto 2010.

SANTOS, Paulo Fernando dos. Lei de Execução Penal - Comentada e Anotada. São Paulo: Leud,1999.

TRISOTTO, Sabrina. O Trabalho prisional como instrumento de reabilitação social: uma perspectiva crítica. 2005. Disponível em <http://www. tede.ufs.br/teses PEEDO 534. pdf>. Acesso em: 31 agosto 2009. 